\title{
Aggressive Nasal Type Extranodal Natural killer/T-cell Lymphoma Presenting as Refractory Granulomatosis with Polyangiitis (Wegener's Granulomatosis)
}

\author{
Andreea-Alexandra Aldea', Anca Bojan², Laura Muntean³, Simona Rednic ${ }^{3}$
}

\begin{abstract}
Background: Extranodal NK/T-cell lymphoma, nasal type is a locally invasive tumour, including ulcerative and necrotic lesions, preferentially originating in the nasal cavities and sinuses. It can be frequently confused with a localized form of granulomatosis with polyangiitis (GPA, formerly known as Wegener's granulomatosis), which affects the upper respiratory tract through the same kind of destructive lesions. Case presentation: A 39-year-old man with bilateral nasal obstruction, purulent rhinorrhea, oro-pharyngeal pain, anosmia, halitosis, severe upper dysphagia, and nasal dysmorphism was referred for rheumatologic reevaluation. Over 2 years of evolution, multiple nasal biopsies were performed showing chronic granulomatous inflammation and necrosis, with no malignant cells. Although antineutrophil cytoplasmic antibodies test was negative, the patient was diagnosed with GPA and treated with corticosteroids and immunosupressors. The disease worsened progressively, leading to destructive lesions of the naso-sinusal region. A new biopsy revealed this time atypical lymphoid cells. Upon immunohistochemical characterization, the atypical cells showed CD3+ and granzyme B+ phenotype. In addition, Epstein-Barr virus was identified. Thereafter, nasal type of extranodal NK/T-cell lymphoma was confirmed. The patient underwent chemotherapy regimen with favourable outcome. Conclusion: When evaluating a patient with destructive midline lesions, clinical suspicion for extranodal NK/T-cell lymphoma, nasal type is necessary. Multiple, large enough biopsies and immunohistochemistry studies are helpful for diagnosis.
\end{abstract}

Keywords: extranodal NK/T-cell lymphoma, granulomatosis with Poliangiitis (GPA), Epstein-Barr virus(EBV), immunohistochemistry

\begin{abstract}
Introducere: Limfomul extranodal NK/T de tip nazal este o tumoră local invazivă, caracterizată prin leziuni ulcerative și necrotice cu originea în cavitățile nazale și în sinusurile paranazale. Poate fi cu ușurință confundat cu o formă localizată a granulomatozei cu poliangiită (granulomatoza Wegener), care afectează căile respiratorii superioare prin același tip de leziuni. Prezentare de caz: Un pacient în vârsta de 39 de ani s-a prezentat în departamentul de reumatologie cu următoarele acuze: obstrucție nazală bilaterală, dismorfism nazal, rinoree purulentă, durere orofaringiană, anosmie, halitoză, disfagie. Timp de doi ani s-au recoltat biopsii, care au relevat inflamație granulomatoasă cronică și necroză, fără celule maligne. S-a stabilit diagnosticul de granulomatoză cu poliangiita și s-a instituit
\end{abstract}

1 "Iuliu Hatieganu" University of Medicine and Pharmacy, Cluj-Napoca, Romania

${ }^{2}$ Department of Hematology, „Prof. Dr. Ion Chiricuta” Institute of Oncology, Cluj-Napoca, Romania

${ }^{3}$ Department of Rheumatology, County Emergency Hospital,

Cluj-Napoca, Romania

\section{Corresponding author.}

Laura Muntean, Department of Rheumatology, County

Emergency Hospital, Cluj-Napoca, Romania.

E-mail: Imuntean13@yahoo.com 
tratament cu corticosteroizi și imunosupresoare. Boala a evoluat, însă, progresiv cu deteriorarea stării pacientului. A cincea biopsie a evidențiat limfocite atipice, iar testul imunohistochimic a exprimat fenotipul CD3 + citoplasmatic și Granzime B+. Virusul Epstein-Barr a fost, de asemenea, identificat. S-a stabilit diagnosticul final de limfom extranodal NK/T, de tip nazal. Pacientul a urmat tratament chimioterapic, la care boala a remis complet. Concluzie: În cazul evaluării unui pacient cu leziuni distructive la nivelul cavității nazale, trebuie suspectat un limfom extranodal NK/T, de tip nazal. Biopsii multiple, pe arii extinse și testarea imunohistochimică sunt necesare în depistarea diagnosticului.

Cuvinte cheie: limfom extranodal NK/T, granulomatoza cu poliangiită, virusul Epstein-Barr, imunohistochimie

\section{BACKGROUND}

We present a rare case of nasal type extranodal NK/Tcell lymphoma mimicking granulomatosis with polyangiitis (GPA), in order to highlight the difficulties in the differential diagnosis of destructing nasal lesions. Extranodal NK/T-cell lymphoma, nasal type is a rare type of non-Hodgkin's lymphoma, often associated with Epstein-Barr virus (EBV) infection, characterised by destructive lesions arising in the naso-sinusal tract and progressively invading the midfacial bones. Early diagnosis can be very challenging because clinicopathological findings overlap with various diseases including infections, necrotizing vasculitis, and neoplastic lesions. GPA is a necrotizing granulomatous vasculitis associated with antineutrophil cytoplasmic antibodies (ANCA) that affects the upper respiratory tract, the lungs and the kidneys. Limited forms of GPA may be ANCA negative and sometimes lead to destructive midline lesions ${ }^{1}$. Extranodal NK/T-cell lymphoma, nasal type is a serious and in most cases fatal disease, more typical for Asian (China, Japan, Korea, Southeast Asia) and South American (Mexico, Peru, Argentina) populations and very rare between Caucasian patients ${ }^{2}$. The rarity of this kind of lymphoma has now been more clearly elucidated as a result of progress in immunohistochemistry (IHC) and molecular biology ${ }^{3}$.

\section{CASE PRESENTATION}

A 39-year-old man with bilateral nasal obstruction, fetid purulent rhinorrhea, oro-pharyngeal pain, oro-nasal regurgitation of liquids, anosmia, halitosis, severe upper dysphagia, and nasal dismorfism was referred for rheumatologic reevaluation, in July 2017 to the Department of Rheumatology, Cluj-Napoca.

Figure 1. HE40 - atypical lymphoid cells.

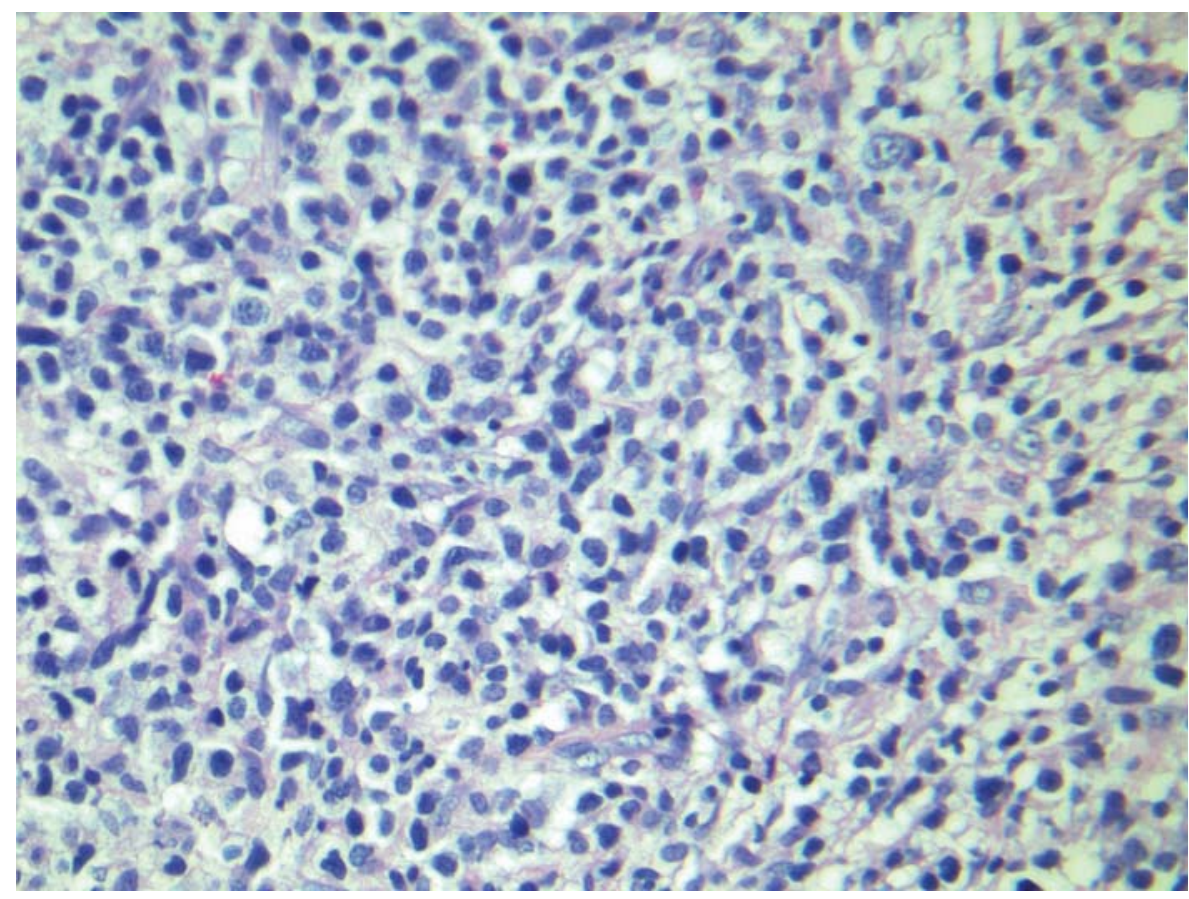


Figure 2. IHC - cytoplasmic CD3 positive.

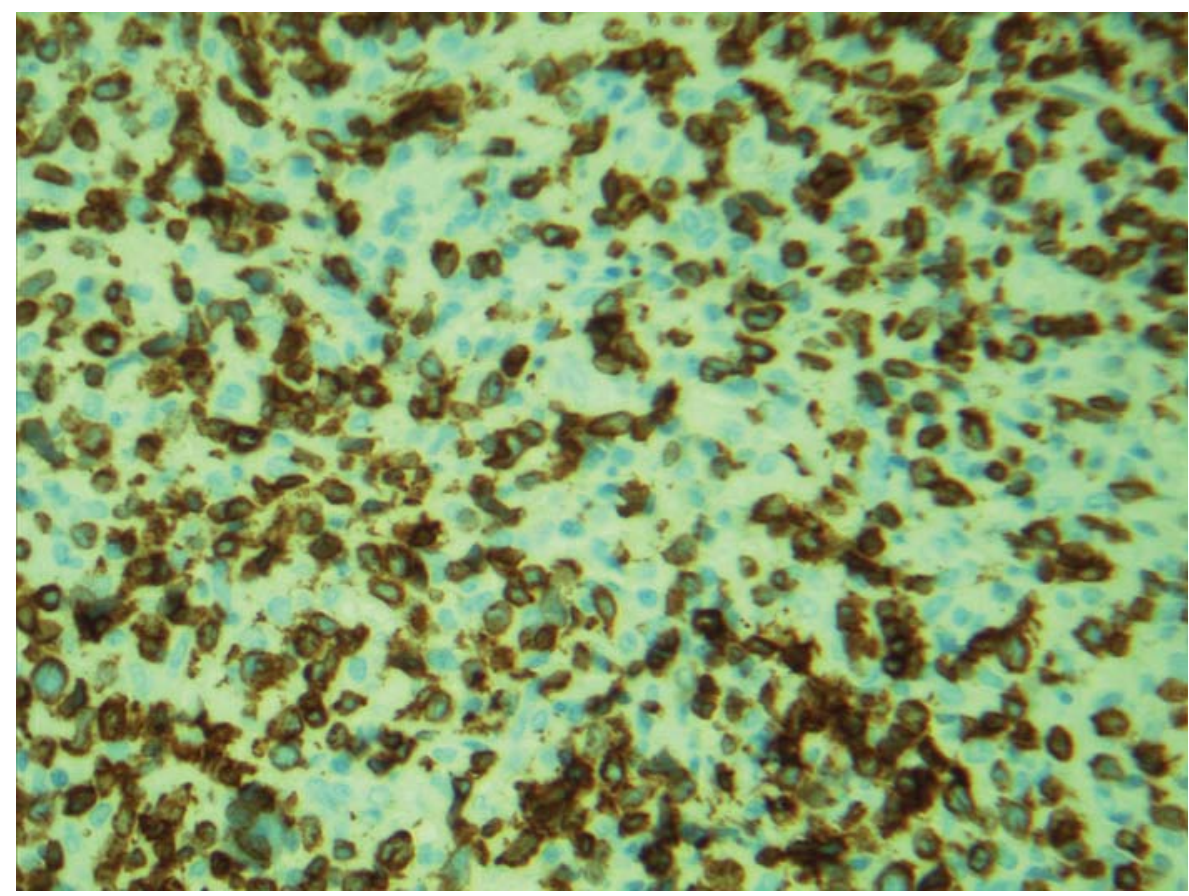

Two years before the admission in our department, in October 2015, at the time of the first symptoms, the patient was referred to the Ear-Nose-Throat Department with progressive nasal obstruction and inflammatory syndrome. The physical and endoscopic examination revealed complete obstruction of the nasal fosse with nasal dysmorphism and degenerated mucosa but no obstruction of the rhinopharynx. The first tissue biopsy was taken with a specimen consisting of left nasal cavity mucosa. The result of the histopathological examination was unclear, which only revealed profuse inflammatory reaction. A diagnosis of chronic sinusitis

Figure 3. IHC - Granzyme B+ phenotype.

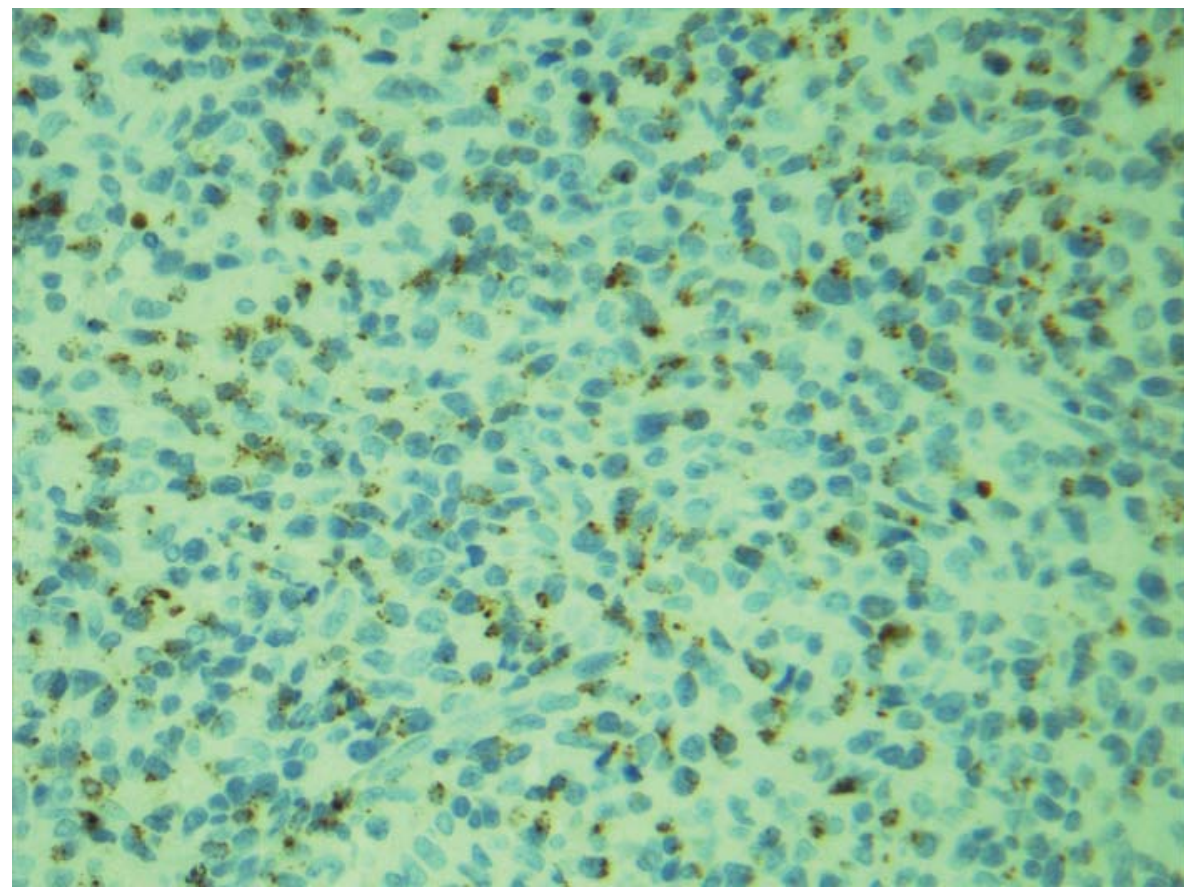


Figure 4. IHC - Ki67 proliferation marker.

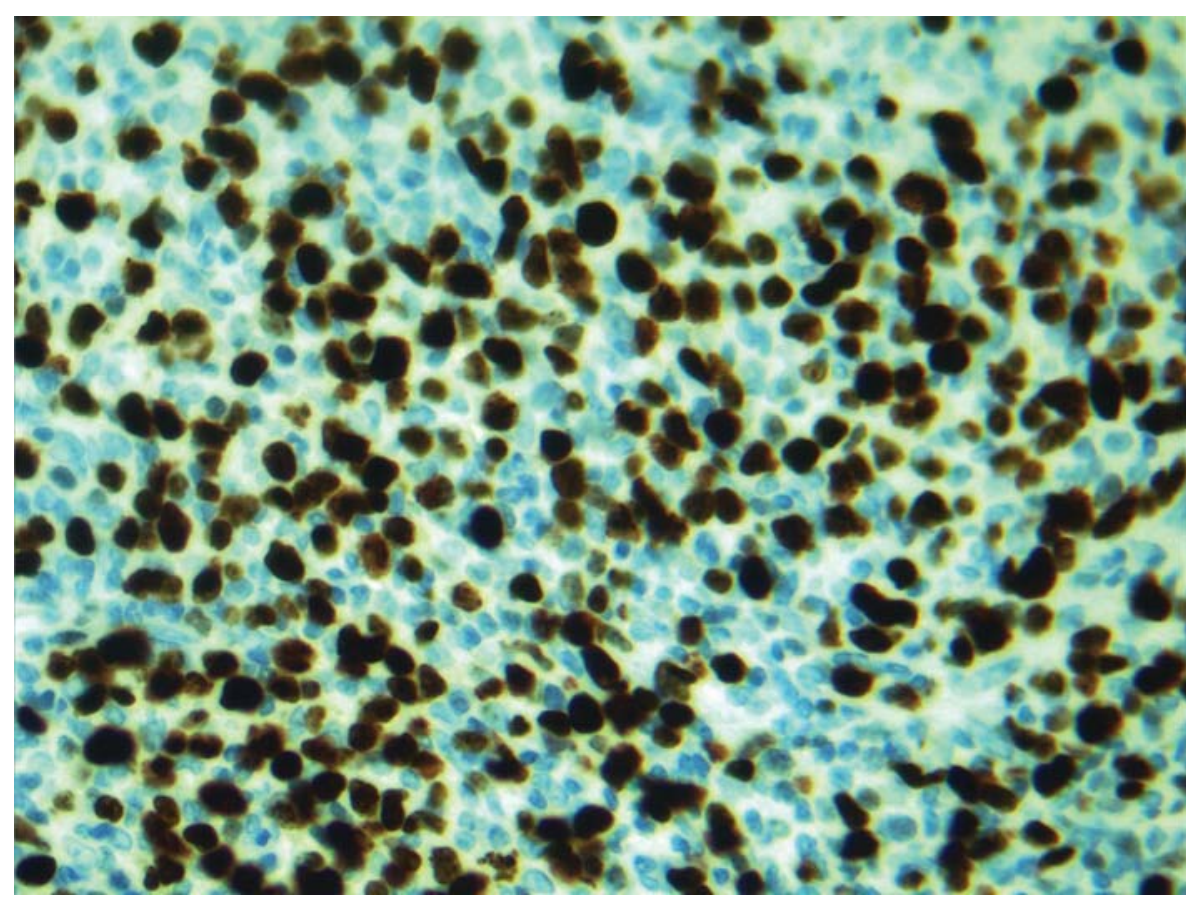

was established and the patient underwent antibiotic and anti-inflammatory therapy, together with nasal decongestants. Head computed tomography scans showed a homogenous soft tissue mass with obliteration of the left nasal cavity and maxillary sinuses and osteolytic lesions of the midline bones.
The following three biopsies performed from October 2015 until Januar 2016 presented solely aspects of reactive lymphoid hyperplasia. However, in March 2016, a new biopsy was taken for a histopathological analysis; the three biopsy specimens consisted of mucosa of each nasal cavity and from the rhinopharynx.

Figure 5. In situ hybridization - Epstein Barr Virus (EBV)-encoded RNA (EBER)

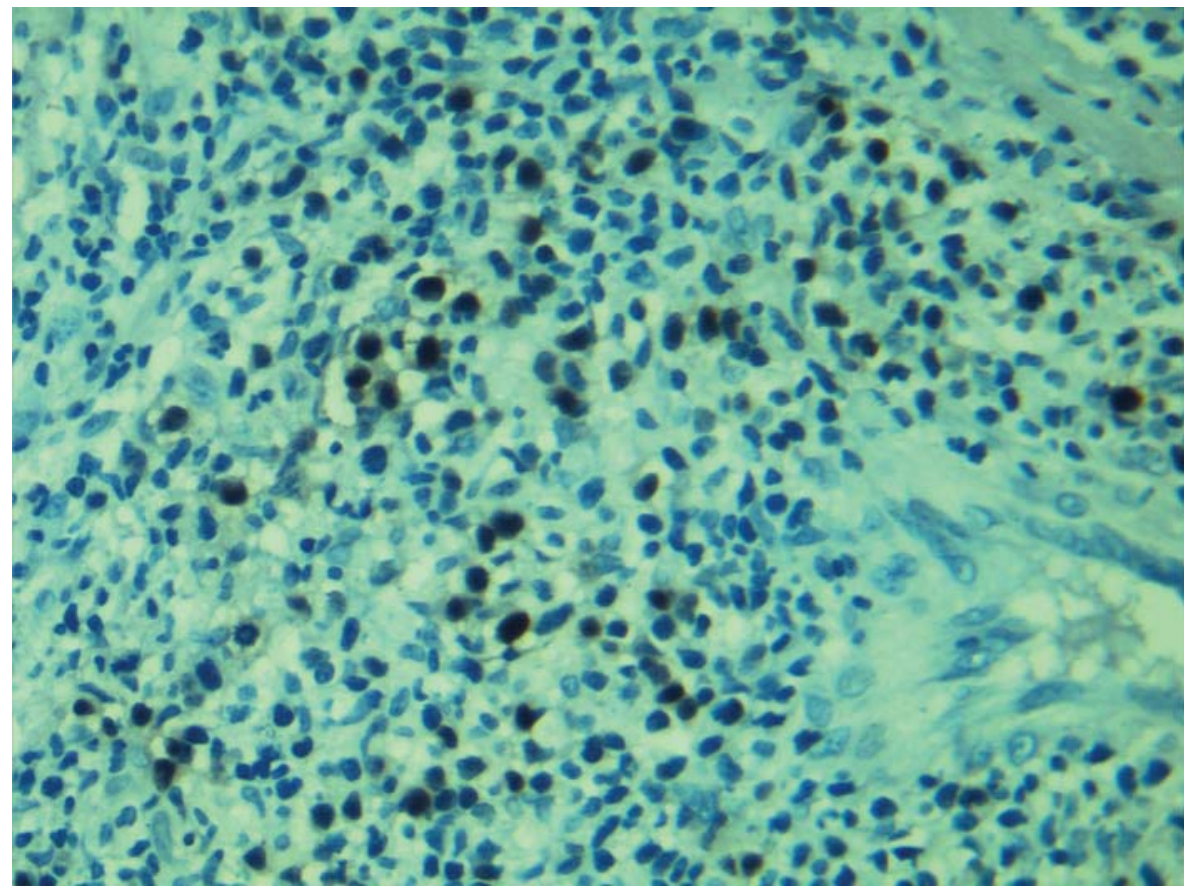


The result in hematoxylin-eosin (H-E) and periodic acid-Schiff (PAS) staining showed, this time, an intense granulocytic infiltrate with the tendency to form granulomas and extensive areas of necrosis, with no malignant cells. The first differential diagnoses taken into account were the following: nasal inflammatory polyp, eosinophilic granulomatosis with polyangiitis (formerly known as Churg-Strauss syndrome) and GPA.

The paraclinical investigations showed leukocytosis, anaemia, important inflammatory syndrome $(\mathrm{CRP}=6.7$ $\mathrm{mg} / \mathrm{dl}$, ESR=60 $\mathrm{mm} / \mathrm{h}$ ); the bacteriological examination was negative and the blood level of procalcitonin was low. Although ANCA was negative, the histopathologic examination suggested GPA. The patient was treated with oral corticosteroids - Methylprednisolone and immunosuppresors - Azathioprine.

Unfortunately, the disease worsened progressively a few months later. Despite the administration of antibiotics, corticosteroids, addition of Methotrexate and endoscopic aspiration of nasal secretions, rapid destruction of the naso-sinusal region, purulent rhinorrhoea, halitosis, inappetence, fever of $40^{\circ} \mathrm{C}$ and dehydration occurred. Careful examination revealed granulomatous lesions of the lateral pharyngeal walls with narrowing of the oropharyngeal isthmus. The endoscopic debridement of the invading tissue was unsuccessful.

A group of doctors, consisting of a rheumatologist, otorhinolaryngologist, hematologist and a pathologist cooperated to establish the possibility of a midline lymphoma as differential diagnosis with GPA. A new rhinopharynx biopsy was performed and the histopathological examination unveiled scattered atypical lymphoid cells with atypical nuclei and clear cytoplasm (Figure 1).

Upon immunohistochemical characterization, the atypical cells showed cytoplasmic CD3+ (Figure 2) and granzyme $\mathrm{B}+$ phenotype (Figure 3 ) as well as the pKi67 proliferative marker (Figure 4). Moreover, using in situ hybridization, EBV encoded RNA (EBER) was identified (Figure 5). The new morphological picture with the IHC profile, together with the entire clinical aspect pointed toward a diagnosis of extranodal NK/Tcell lymphoma, nasal type. The patient was transferred in September 2017 to the Department of Hematology.

Treatment: The first treatment that the patient had underwent was a concurrent chemoradiation therapy with VIPD (Etoposide, Ifosfamide, Cisplatin, Dexamethasone) and radiation. The endoscopic reevaluation showed non-remission of the disease thus, three cycles of AspaMetDex (Escherichia coli L-asparaginase, Methotrexate, Dexamethasone) were added as chemotherapy regimen. The main side effects after chemotherapy were anaemia, medullary aplasia, allergic reaction with anaphylactic shock (angioedema, hypotension and bronchospasm) due to L-asparaginase and an acute faringitis with multidrug-resistant Candida krusei. Therefore, the patient was transfused with two units of erythrocyte mass, granulocyte colony stimulating factor, antifungal and antibiotic treatment were administrated and L-asparaginase was totally removed from the therapeutic formula.

Outcome and follow-up: The patient's outcome was one of complete recovery. Head CT scan showed complete remission of the lymphoma. Autologous hematopoietic stem cell transplantation (HSCT) was considered when remission was achieved, but the patient refused the treatment. He is referred now for periodic controls.

\section{DISCUSSION}

It is a case on the edge of rheumatology and hematology and it illustrates the need of suspicion of an extranodal NK/T-cell lymphoma, nasal type in a background of chronic sinusitis mimicking GPA. The initial signs and symptoms of recurrent sinusitis, as well as the midline localization of the necrotic lesions with nasal soft tissue and bone invasion appear both in GPA and in extranodal NK/T-cell lymphoma, nasal type.

Another similar case report, published in The American Journal of the Medical Sciences, presented the case of a patient with recalcitrant periodontitis, who underwent multiple histopathological examinations which suggested GPA. Eventually, the final biopsy together with the phenotypic markers pointed toward a diagnosis of extranodal, nasal type NK/T-cell lympho$\mathrm{ma}^{4}$. Another study compared the clinical course of patients diagnosed with sinonasal T-cell lymphoma with other recently treated patients with GPA in the upper airways and asserts that clinically, it may be almost impossible in the early stages of the disease to differentiate between T-cell lymphoma, GPA and nonspecific chronic inflammation. One third of the T-cell lymphoma patients had a history of persistent „chronic rhinitis" for several years before the disease evolved into an ulcerative stage ${ }^{5}$. What led to further diagnostic dilemma in our case was the missing ANCA, which is usually a characteristic marker for GPA, but still not detectable in a quarter of patients with limited $\mathrm{GPA}^{6}$. 
Nevertheless, there are some differences between the two pathological entities. Firstly, clonal EpsteinBarr virus (EBV) infection is almost invariably involved in nasal NK/T-cell lymphomas, appearing in 90\% of cases, whereas between GPA and EBV there is no correlation $^{7,8}$. Beside the etiological role of the EBV in extranodal NK/T-cell lymphomas, the virus has been shown to shape the tumor microenvironment by encoding a series of products that mimic several growth, transcription and anti-apoptotic factors, and in this way taking control over tumour cells pathways ${ }^{9-11}$. Our case consolidates these findings, as our patient was detected with EBV-encoded RNA in the neoplastic cells. We want to underline the statement that we have to look in detail when we suspect a midline lymphoma and correlate the viral infection with oncogenicity.

Secondly, histologically, lesions present a mixture of inflammatory cells and diffuse infiltrate of lymphoid cells together with substantial necrotic tissue, which make it difficult to distinguish between infectious, autoimmune or malignant processes ${ }^{4}$. The first three biopsies showed reactive lymphoid hyperplasia, the fourth, necrosis and small sized lymphocytes with the tendency to form granulomas, suggesting the picture of GPA. Only the fifth consistent biopsy unveiled the easily overlooked neoplastic cells, which present as small lymphocytes with nuclear atypia. Because the progressive necrosis and the inflammatory infiltrate covers the entire view of the histological picture, multiple, large enough biopsies specimens are required, to dig after scattered malignant cells ${ }^{4}$.

However, from IHC point of view, NK-T cell lymphoma exhibits a very specific and individual feature. Therefore, once we have an adequate biopsy, IHC is the key for differentiating the two diagnoses from one another ${ }^{7}$. Our case wants to point out that histopathological exam is insufficient for the complete diagnosis of nasal extranodal NK/T-cell lymphoma and that performing immunohistochemistry is crucial in defining the diagnosis and differentiating it from GPA. Nasal extranodal NK/T-cell lymphoma arise from the malignant transformation of NK cells and express CD2, CD56, cytoplasmic CD3, perforin, and granzyme B2,5. Immunophenotypically, our patient presented cytoplasmic CD3+, granzyme B+, and negative CD56.
Ki67 is a proliferation marker, firmly associated with tumor cell proliferation and growth and is correlated with tumor aggressiveness ${ }^{13}$. The expression of Ki67 was found in our case and was a diagnostic and prognostic marker.

Third, what indicates a diagnosis other than GPA, is the non-response to Azathioprine and the rapidly, progressively deterioration of the patient's clinical course.

The medical literature presents a large spectrum of differential diagnoses for destructive midline lesions. GPA, Churg Strauss syndrome, sarcoidosis, systemic lupus erythematousus, Sjögren's syndrome, syphilis, as well as cocaine abuse are just a few of them ${ }^{4,7}$. Despite diagnostic advances and improved understanding of the disease, an etiology is often not identified ${ }^{14}$. Therefore, a multidisciplinary collaboration between rheumatologists, otorhinolaryngologists, hematologists and experienced pathologists is required.

\section{Take home messages}

- A nasal obstruction with purulent rhinorrhea and destructive midline lesions may be the initial signs of the extranodal, nasal type, NK/T-cell lymphoma under the mask of a GPA.

- Multiple, large enough biopsies, immunohistochemistry studies and appropriate serological tests are the key in finding the correct diagnosis.

- The finding of EBV in the tumoral cells is an essential part in the diagnosis of NK/T-cell lymphoma.

\section{Acknowledgements:}

The authors want to thank Dr. Bogdan Fetica from Oncologic Institute „Prof. Dr. Ion Chiricuță”, ClujNapoca, Department of Pathological Anatomy for providing the biopsy and immunhystochemistry images from Figure 1-5.

\section{Compliance with ethics requirements:}

The authors declare no conflict of interest regarding this article.

The authors declare that all the procedures and experiments of this study respect the ethical standards in the Helsinki Declaration of 1975, as revised in 2008(5), as well as the national law. Informed consent was obtained from all the patients included in the study. 


\section{References}

1. Pagnoux C. Updates in ANCA-associated vasculitis. Eur J Rheumatol. 2016 Sep; 3(3): 122-133

2. Eric Tse, Yok-Lam Kwong. How I treat NK/T-cell lymphomas. Blood 2013;121(25):4997-5005

3. Tababi S., Kharrat S., Sellami M., Mamy J., Zainine R., Beltaief N., Sahtout S., Besbes G. Extranodal NK/T-cell lymphoma, nasal type: Report of 15 cases. European Annals of Otorhinolaryngology, Head and Neck Diseases 2012 June; 129(3): 141-147

4. Sokołowska-Wojdyło M., Florek A., Baranska-Rybak W., Sikorska M., Starzynska A., Drogoszewska B., Włodarkiewicz A. Natural Killer/T-Cell Lymphoma, Nasal Type, Masquerading as Recalcitrant Periodontitis in a Patient With a Diagnosis of Wegener's Granulomatosis. The American Journal of the Medical Sciences. 2013;345(2):163-167

5. Cervin A., Dictor M., Kalm O. Sinonasal T-cell Lymphoma and Wegener's Granulomatosis: Aspects in Early Differential Diagnosis. American Journal of Rhinology. 1996;10(4): 239-246

6. Pakalniskis M. G., Berg A. D., Policeni B. A., Gentry L. R., Sato Y., Moritani T., . Smoker W. R. K. The Many Faces of Granulomatosis With Polyangiitis: A Review of the Head and Neck Imaging Manifestations. Neuroradiology/Head and Neck Imaging. 2015 Dec;205(6):619-629
7. Lee YT, Chang YS, Lai CC, et al. Natural killer (NK)/T-cell lymphoma mimicking granulomatosis with polyangiitis (Wegener's). Scand J Rheumatol 2012;41:407-8.

8. Kwong Y-L. Natural killer-cell malignancies: diagnosis and treatment. Leukemia 2005; 19: 2186-2194

9. Gru A. A., Haverko B. H., Freud A. G., Hastings J., Nowacki N. B., Barrionuevo C., Vigil C. E., Rochford R., Natkunam Y., Baiocchi R. A., Porcu P. The Epstein-Barr Virus (EBV) in T Cell and NK Cell Lymphomas: Time for a Reassessment. Curr Hematol Malig Rep. 2015 Dec; 10(4): 456-467

10. Cai Q., Chen K., Young K.H. Epstein-Barr virus-positive T/NKcell lymphoproliferative disorders. Experimental \& Molecular Medicine. 2015 Jan; 47(1):e133

11. Semenzato G., Marino F., Zambello R. State of the art in natural killer cell malignancies. Int J Lab Hematol. 2012 Apr;34(2):11728

12. Tlholoe M. M., Kotu M., Khammissa R. AG., Bida M., Lemmer J., Feller L. Extranodal Natural Killer/T-cell lymphoma, nasal type: 'midline lethal granuloma.' A case report. Head Face Med. Jan 2013;9(4)

13. Li L. T., Jiang G., Chen Q., Jun N. Zheng. Ki67 is a promising molecular target in the diagnosis of cancer (Review). Molecular Medicine reports. November 2014;11(3):1566-1572

14. Parker, N.P., Pearlman, A.N., Conley, D.B., Kern, R.C., Chandra, R.K. The dilemma of midline destructive lesions: a case series and diagnostic review. Am J Otolaryngol. 2010;31:104-9. 
